\title{
A modeling study of benthic detritus flux's impacts on heterotrophic processes in Lake Michigan
}

\author{
Changsheng Chen, ${ }^{1}$ Lixia Wang, ${ }^{1}$ Jianhua Qi ${ }^{1}$ Hedong Liu, ${ }^{1}$ Judith Wells Budd, ${ }^{2}$ \\ David J. Schwab, ${ }^{3}$ Dmitry Beletsky, ${ }^{4}$ Henry Vanderploeg, ${ }^{3}$ Brian Eadie, ${ }^{3}$ \\ Thomas Johengen, ${ }^{3}$ James Cotner, ${ }^{5}$ and Peter J. Lavrentyev ${ }^{6}$ \\ Received 20 October 2002; revised 13 November 2003; accepted 4 February 2004; published 21 July 2004.
}

[1] Effects of sediment resuspension-induced benthic detrital flux on the heterotrophic part of the microbial food web in Lake Michigan were examined using a threedimensional (3-D) coupled biological and physical model. The model was driven by the realistic meteorological forcing observed in March 1999. Wind-induced surface wave dynamics were incorporated into the physical model to generate the bottom flux. The model-generated benthic detrital flux was assumed to be proportional to the difference between model-calculated and critical stresses at the bottom. The model results indicate that detrital flux at the bottom was a key factor causing a significant increase of phosphorus and detritus concentrations in the nearshore region of the springtime plume. Inside the plume the sediment-resuspended bottom detritus flux could directly enhance heterotrophic production, while outside the plume, detrital flux from river discharge might have a direct contribution to the high abundance of bacteria and microzooplankton in the nearshore region. Model-data comparison on cross-shore transects near Chicago, Gary, St. Joseph, and Racine suggests that other physical and biological processes may play a comparative role as the bottom detritus flux in terms of the spatial distribution of bacteria and microzoplankton. A more complete microbial food web model needs to be developed to simulate the heterotrophic process in southern Lake Michigan. INDEX TERMS: 4815 Oceanography: Biological and Chemical: Ecosystems, structure and dynamics; 4804 Oceanography: Biological and Chemical: Benthic processes/benthos; 4255 Oceanography: General: Numerical modeling; 4817 Oceanography: Biological and Chemical: Food chains; KEYWORDS: microbial food web, Pelagic coupling, coupled biological and physical model

Citation: Chen, C., et al. (2004), A modeling study of benthic detritus flux's impacts on heterotrophic processes in Lake Michigan, J. Geophys. Res., 109, C10S11, doi:10.1029/2002JC001689.

\section{Introduction}

[2] Recurrent episodic resuspension events in southern Lake Michigan raise a fundamental question regarding the effect of benthic detritus flux in heterotrophic production in the coastal region of the lake. Recent field measurements revealed that heterotrophic bacterial productivity increased significantly during the resuspension events [Cotner et al., 1999; Cotner, 2000]. Since autotrophic production remained at a very low level because of light

\footnotetext{
${ }^{1}$ School for Marine Science and Technology, University of Massachusetts-Dartmouth, New Bedford, Massachusetts, USA.

${ }^{2}$ Department of Geological Engineering and Sciences, Michigan Technological University, Houghton, Michigan, USA.

${ }^{3}$ NOAA Great Lakes Environmental Research Laboratory, Ann Arbor, Michigan, USA.

${ }^{4}$ Department of Naval Architecture and Marine Engineering, University of Michigan, Ann Arbor, Michigan, USA.

${ }^{5}$ Department of Ecology Evolution and Behavior, University of Minnesota, St. Paul, Minnesota, USA.

${ }^{6}$ Department of Biology, University of Akron, Akron, Ohio, USA.

Copyright 2004 by the American Geophysical Union. 0148-0227/04/2002JC001689
}

limitation within the plume, heterotrophic bacteria was decoupled from the autotrophic process. Thus benthicpelagic exchange at the bottom was believed to be a key source for growth of bacteria in the coastal region [Cotner, 2000; Cotner and Biddanda, 2002]. This finding was supported by our process-oriented modeling studies of the 1998 and 1999 plume events in southern Lake Michigan [Chen et al., 2002; Ji et al., 2002; Chen et al., 2004]. The model-predicted matter flux in the food web clearly shows that the impact of the suspended sediment plume on the ecosystem in southern Lake Michigan was reflected at the heterotrophic level, primarily at the level of the microbial food web consisting of detritus, bacteria and microzooplankton.

[3] Highly reflective, recurrent coastal plumes have been repeatedly documented in the satellite imagery during early spring in southern Lake Michigan [Mortimer, 1988; Budd et al., 2000; Warrington et al., 2000]. Field measurements taken in March 1998 and 1999 and previous modeling experiments clearly showed that the plume was caused mainly by wave-driven resuspension of sediment and wind-induced convergence of currents in the coastal region [Eadie et al., 1996; Chen et al., 2002]. The surface area and 


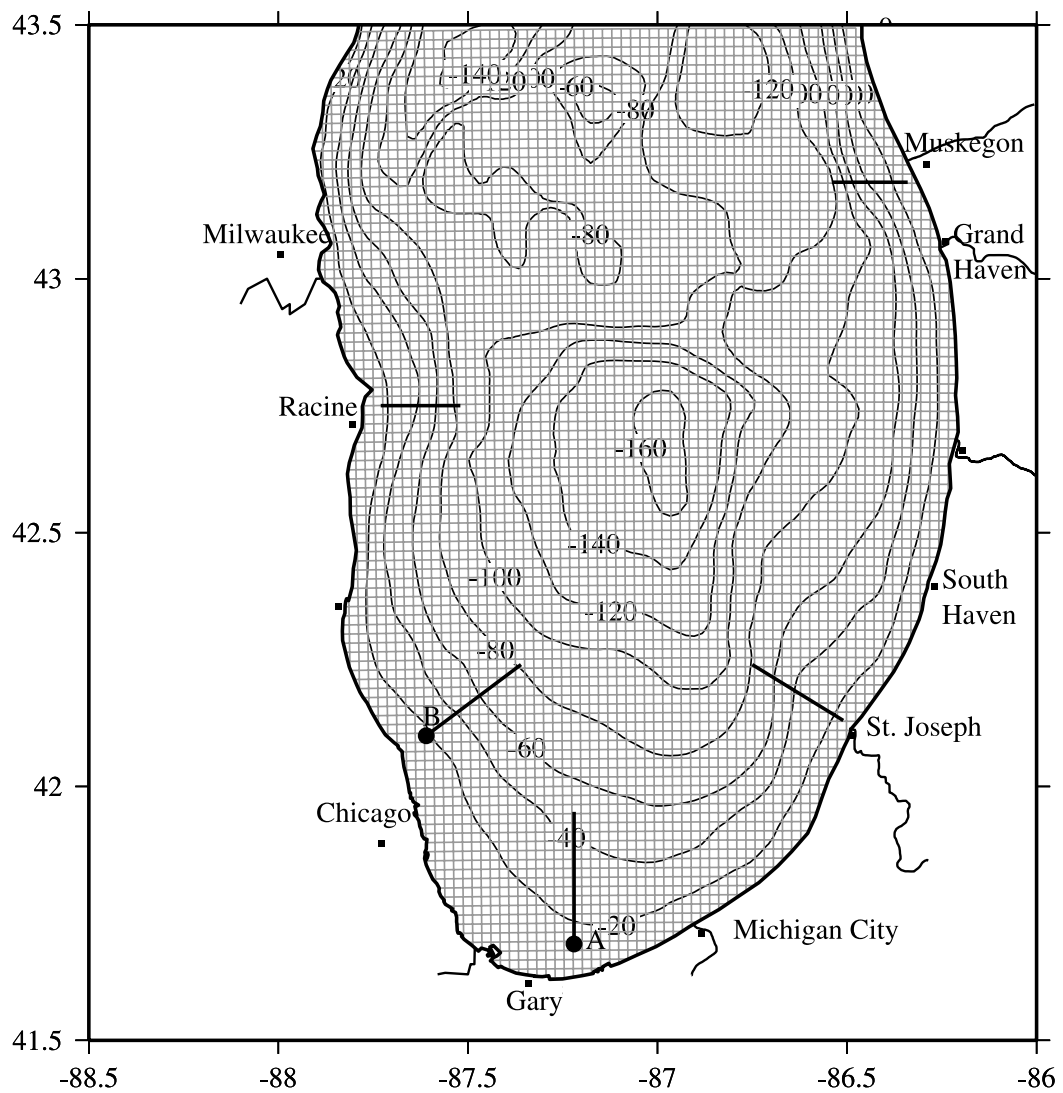

Figure 1. Bathymetry (thin solid curved lines) and model grids in southern Lake Michigan. Heavy solid straight lines represent the cross-isobath transects near Racine, Chicago, Gary, St. Joseph, and Muskegon. Heavy solid curved lines indicate the river path terminated around the lake. Solid dots are the locations of sites used to describe the time series.

intensity of the satellite-derived suspended sediment concentration (SSC) signed in Southern Lake Michigan in March 1999 (Figure 1) were closely coherent with observed surface wind and model-predicted wave heights. For example, at site B near Chicago, a strong southward wind of about $10-15 \mathrm{~m} / \mathrm{s}$ occurred on 5-7 March, which led to a wave height of about $3 \mathrm{~m}$ at the 20-m isobath in the northern coast of Chicago (Figures $2 \mathrm{a}$ and $2 \mathrm{~b}$ ) and a high SSC of $>20 \mathrm{mg} / \mathrm{L}$ (Figure 2c). Since water in southern Lake Michigan remained well mixed from the surface to the bottom in March 1999, the high value of the SSC implied an intensive sediment resuspension from the bottom [Chen et al., 2004].

[4] However, both observations and model results suggested that wind-induced waves were not the only physical mechanism for the occurrence of the plume [Beletsky et al., 2003]. An example can be seen from a time series of wind stress, wave height, and SSC at site B shown in Figure 2. The SSC continuously decreased with time after 7 March, even during a subsequent relatively strong $(\sim 10 \mathrm{~m} / \mathrm{s})$ southward wind and high wave events occurring on 15-25 March. The distribution of SSC observed in March 1999 was consistent with the model-predicted spatial distribution of the flow's convergence and bottom stress (Figure 3). The strong southward wind, which occurred on 5-7 March, produced a relatively strong southward flow along both sides of the lake, leading to a significant convergence of water toward the south-south- western coast of southern Lake Michigan on 6 March. Correspondingly, a strong bottom stress appeared in the convergence zone, which directly contributed to sediment resuspension in the nearshore region of the south-southwestern coast on 7 March (Figure 3a). The area of high SSC shrunk southward with time during 7-19 March as a result of weakening of water currents and bottom stress along the southwestern coast (Figures $3 \mathrm{~b}$ and $3 \mathrm{c}$ ). Noticeable sediment resuspension was observed again after $20 \mathrm{March}$, in correspondence to intermittent southward wind events and enhanced bottom stress that occurred during the period (Figure 3d).

[5] Our previous modeling experiments suggest that sediment resuspension plays a critical role in supplying nutrients in southern Lake Michigan [ $\mathrm{Ji}$ et al., 2002]. In terms of nutrient cycling dynamics, during plume events, detritus in the benthic layer could be resuspended into the water column and then converted to inorganic nutrients by remineralization. In our previous modeling studies, nutrients supplied through benthic flux were assumed to be proportional to SSC [Ji et al., 2002; Chen et al., 2004]. This approach, as a first-order approximation, provided a reasonable simulation of spatial and temporal distributions of nutrients during the 1998 and 1999 plume events, but it had two critical deficiencies. First, this assumption missed the role of benthic-pelagic exchange processes in nutrient dynamics in the lake. Since nutrient releases were treated 
a

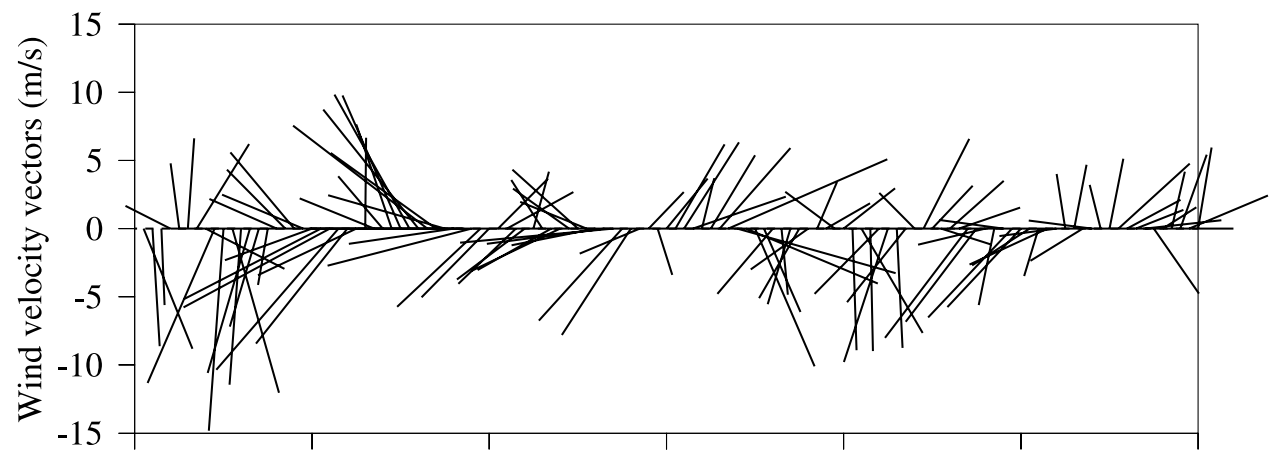

$\mathrm{b}$

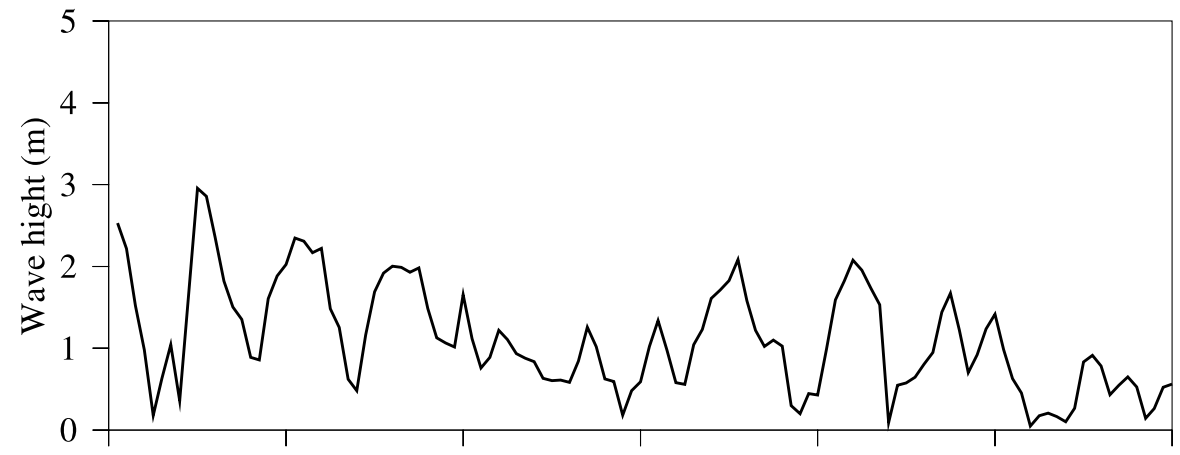

C

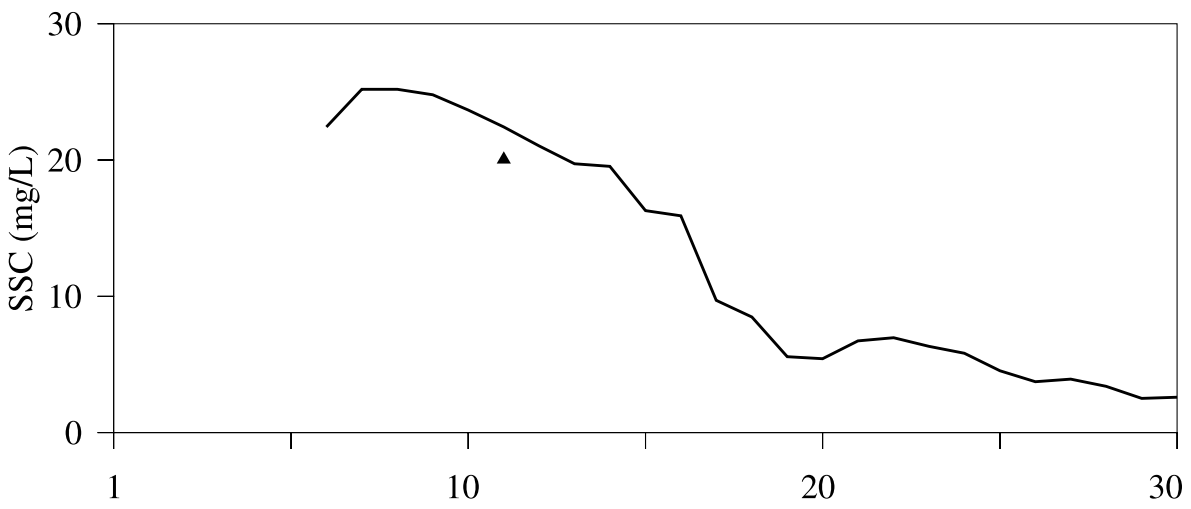

March 1999 (Day)

Figure 2. Time series of surface wind velocity vector $(\mathrm{m} / \mathrm{s})$, wave height $(\mathrm{m})$, and suspended sediment concentration $(\mathrm{mg} / \mathrm{L})$ at site A off Gary and site B off Chicago. Solid triangle shows the suspended sediment concentration measured in water samples during the March 1999 EEGLE cruise.

as an external loading, internal nutrient recycling may have been underestimated in our previous model simulation. This suggests that the model provided a simulation result that was explicitly driven from the unclear physics. Second, the nutrient release term in the model was determined in relationship to the satellite-derived SSC, which was valid only during early spring when the water was vertically well mixed. Therefore this method was reasonable for process-oriented studies of the recurrent spring plume events, but cannot be used to simulate the seasonal variability of the microbial food web in southern Lake Michigan.

[6] In this paper, the impact of wind-induced detrital flux on heterotrophic production is examined using a coupled physical-biological model with inclusion of the physical mechanism of sediment resuspension. A wave model, which was developed for Lake Michigan by Schwab et al. [1984], was incorporated into the physical model, and thus the benthic flux was calculated from the bottom stresses on the basis of current and wave interactions. Studies focus on the mechanism of sediment resuspension-induced detrital flux in internal nutrient recycling and detritus-bacteriamicrozooplankton food web. The model results are validated by a comparison with observed concentrations of nutrients, detritus, bacteria, microzooplankton and zooplankton.

[7] The data used in this paper were collected during the March 1999 EEGLE (Episodic Event-Great Lake Experiment) field cruises on Muskegon, St. Joseph, Gary, Chicago, and Racine (Figure 1). Phosphorus was measured from water samples by the molybdate/ascorbic acid method 


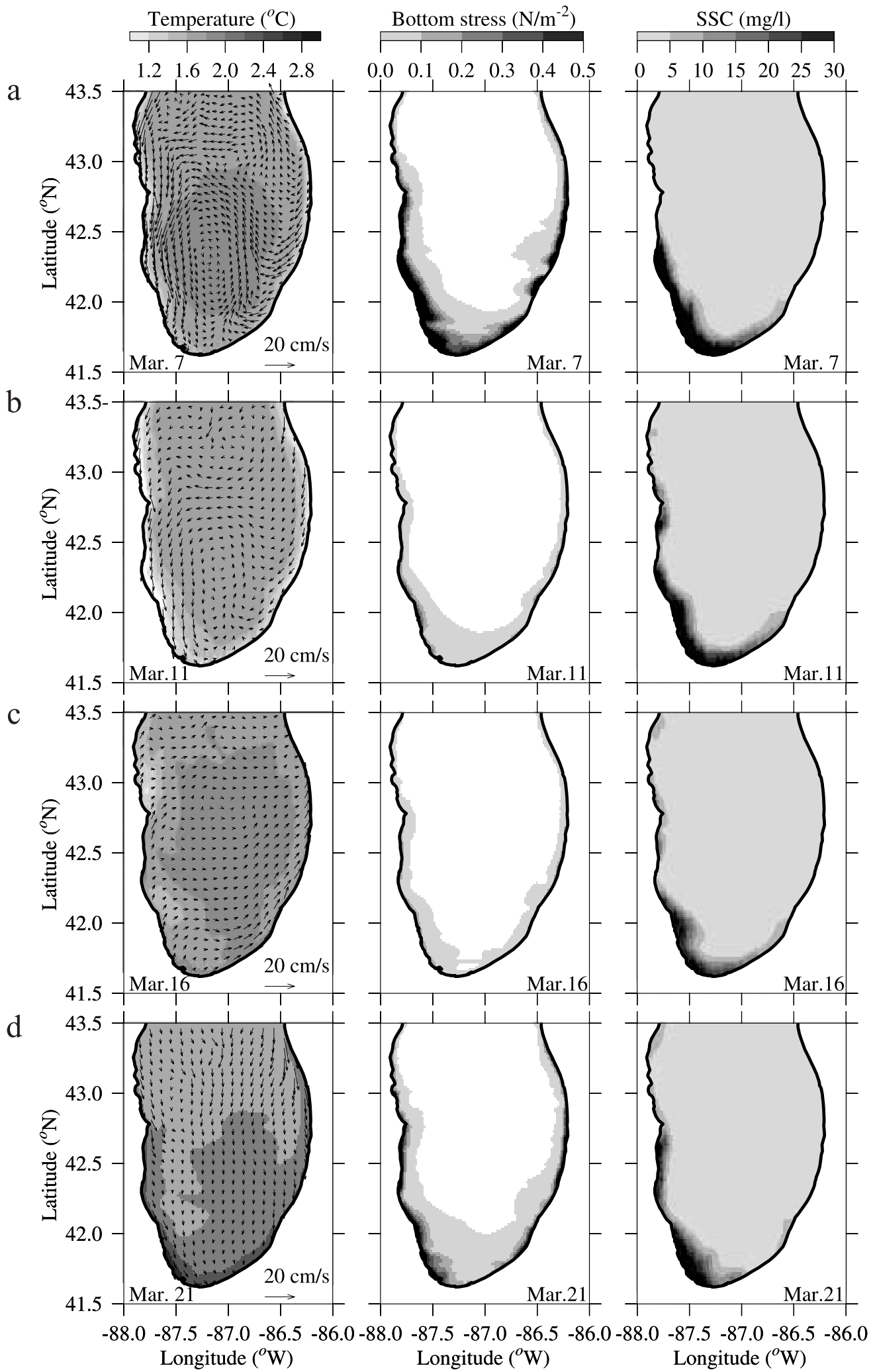

Figure 3. Distributions of model-computed temperature overlapped with surface currents, bottom stress, and satellite-derived suspended sediment concentration on 7, 11, 16, and 21 March of 1999 in southern Lake Michigan. 


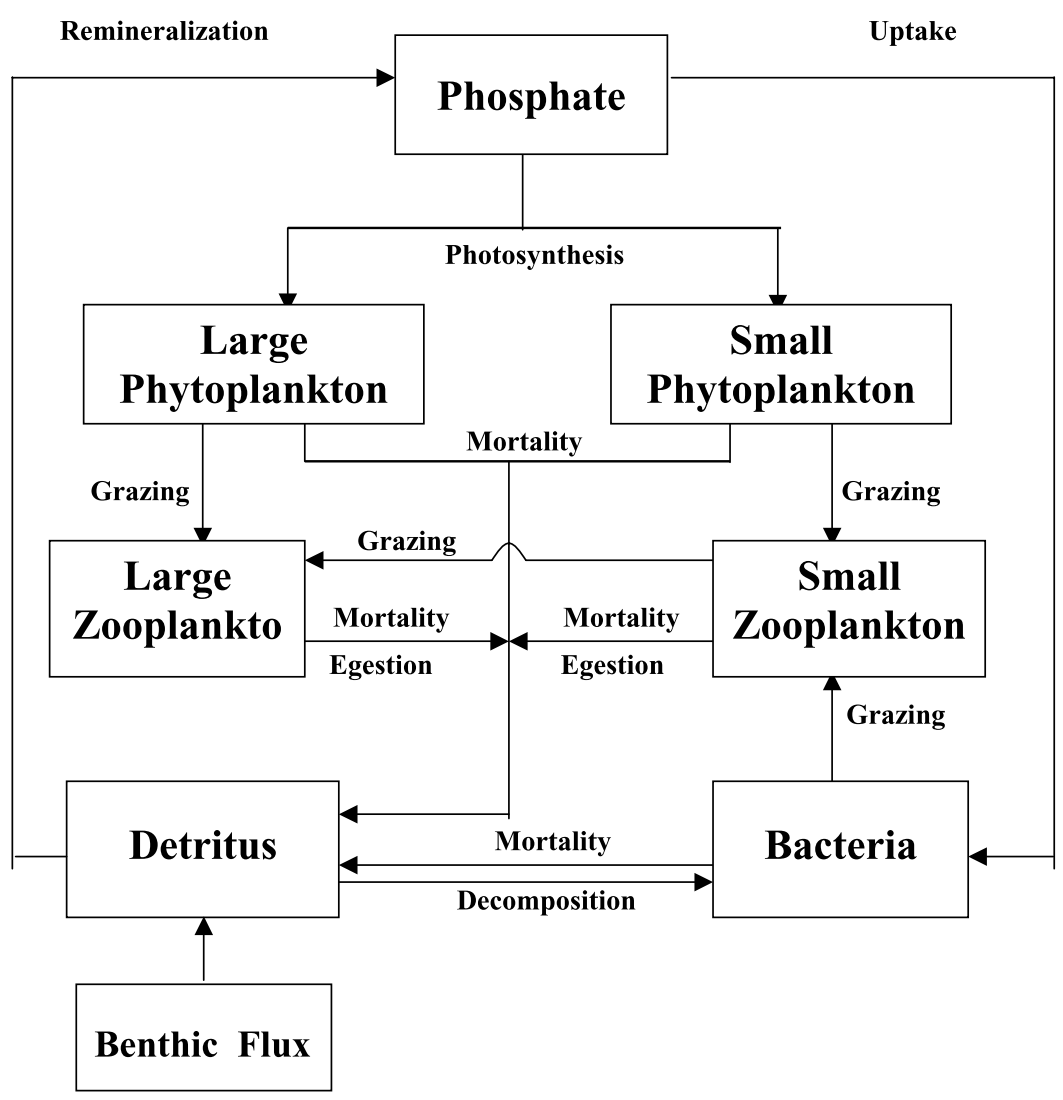

Figure 4. Schematic of the lower trophic level food web model used in this study.

on AutoAnalyzer II. Detritus referred to the particular organic carbon, which was estimated using the Erba CHN elemental analyzer. Bacterial measurements were made with epifluorescence microscopy and microzooplankton were sampled using multiple 10-1 Niskin bottles mounted on a SeaBird carousel water sampler. Zooplankton was measured using the tow-yoed Plankton Survey System (PSS). There data were collected by Tom Johengen, James Cotner, Peter J. Lavrentyev, Henry Vanderploeg, respectively, and were directly downloaded from the EEGLE database.

\section{Design of Numerical Experiments}

[8] The coupled physical and biological model used in this study was developed by Chen et al. [2002]. The physical model is the Princeton Ocean Model (called POM) developed originally by Blumberg and Mellor [1987] and configured for Lake Michigan by Schwab and his coworkers at the NOAA Great Lake Environmental Research Laboratory (NOAA/GLERL) [Schwab et al., 2000; Beletsky et al., 2003]. A uniform grid size of $2 \mathrm{~km}$ was specified in the horizontal and $20 \sigma$ levels were used in the vertical. The biological model represents a phosphoruscontrolled lower trophic level food web system with 7 state variables (Figure 4). Biological variables include $P_{L}$ : large size phytoplankton (diatom in ranges of 13 to $312 \mu \mathrm{m}$ ), $P_{S}$ : small size phytoplankton (small nondiatom: flagellates with a size smaller than $10 \mu \mathrm{m}), Z_{L}$ : large size zooplankton (copepods), $Z_{S}$ : small size zooplankton (ciliates and heterotrophic flagellates), $B$ : bacteria, $D$ : detritus, and $P$ : phosphorus, respectively. Unlike the biological model used in our previous studies [Chen et al., 2002; Ji et al., 2002; Chen et al., 2004], a benthic layer was added as a bottom boundary condition into the model and an upward flux from this layer was directly calculated by the bottom stress derived from wind-induced current and wave interaction. The wind-induced surface waves were estimated using the Lake Michigan parametric dynamical wave prediction model developed by Schwab et al. [1984]. In this model, the wave energy spectrum was parameterized at each point on a rectilinear computational grid in terms of total wave energy, peak energy period, and predominant wave direction. A comparison was made between model-predicted and observed synoptic surface wave fields in Lake Michigan, and the results show that this simple wave model has captured almost all of the synoptic features [Liu et al., 1984].

[9] To examine how benthic detrital flux affects the heterotrophic production, we assumed that there was an infinite spatial uniformly distributed detritus pool at the bottom and detritus flux at the bottom was proportional to the local bottom stress. The surface and bottom boundaries conditions for detrital concentration $(D)$ were specified as

$$
-w_{\mathrm{s}} D+K_{h} \frac{\partial D}{\partial \mathrm{z}}=0, \text { at } z=\zeta(x, y, t)
$$

and

$$
w_{\mathrm{s}} D-K_{h} \frac{\partial D}{\partial \mathrm{z}}=F_{\mathrm{e}}-F_{s}, \text { at } z=-H(x, y),
$$



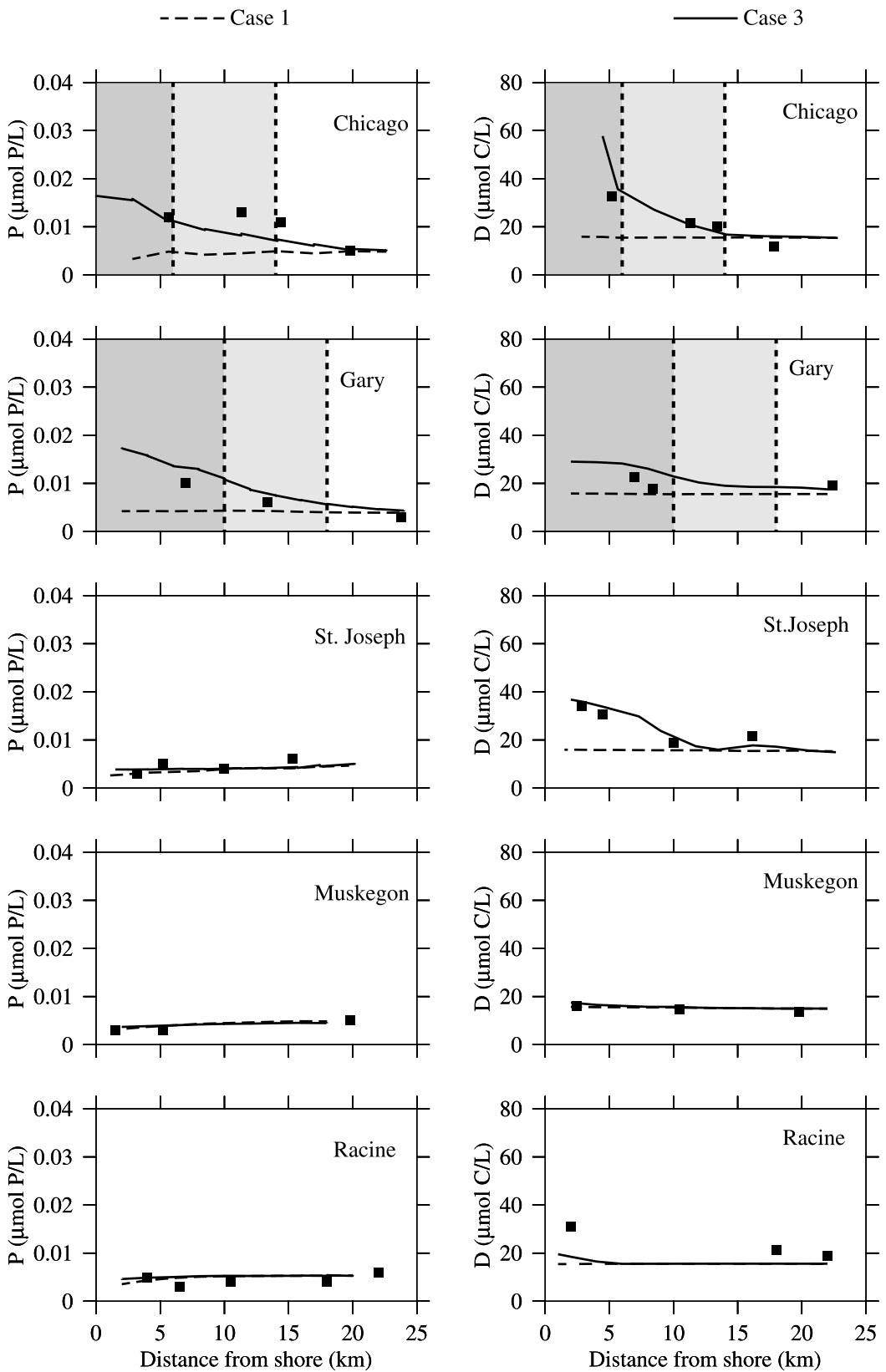

Figure 5. Comparisons of water samples with model-predicted phosphorus and detritus concentrations for numerical experiment cases 1 and 3 at Chicago, Gary, St. Joseph, Muskegon, and Racine transects for the March 1999 plume event. Solid squares indicate water samples. Areas with dark and light shading are the plume zone and transition zone from the plume to the interior.

where

$$
F_{\mathrm{e}}=\frac{c_{e}}{\rho_{0}}\left(\left|\tau_{b}\right|-\tau_{c e}\right)^{+} \text {and } F_{s}=0 ;
$$

$w_{s}$ is the sinking velocity; $K_{h}$ is thermal diffusion coefficient; $F_{e}$ and $F_{s}$ are the suspended detritus fluxes near the bottom caused by resuspension and sedimentation, respectively; $\mathrm{c}_{\mathrm{e}}$ is a proportionality factor specified as $2.5 ; \tau_{\mathrm{b}}$ is the bottom shear stress; $\tau_{\text {ce }}$ is the critical shear stress for resuspension; $z$ is the vertical axis of the orthogonal coordinates; $\zeta$ is the surface elevation; and $H$ is the reference water depth from $z=$ 0 . The superscript ${ }^{+}$is an indicator of the mathematical operator defined as follow: Let $F$ be an arbitrary function and

then $F^{+}=F$ if $F>0$ and $F^{+}=0$ if $F \leq 0$. In this model, the resuspension of bottom detritus only occurs when the bottom shear stress is larger than critical stress for resuspension. For simplification, a spatially uniformly distributed detritus pool was assumed in the benthic layer. This means that the detritus is always available when $\tau_{b}>\tau_{\text {ce. }} . \tau_{c e}$ was specified as $0.13 \mathrm{~N} / \mathrm{m}^{2}$, which was a value used for the simulation study of sediment resuspension by Lou et al. [2000]. This simplification was consistent with our hypothesis that the spatial and temporal distributions of detritus was caused by nonuniform bottom stresses.

[10] The coupled biological and physical model was driven by realistic winds and surface heat fluxes from 
---- Case 1
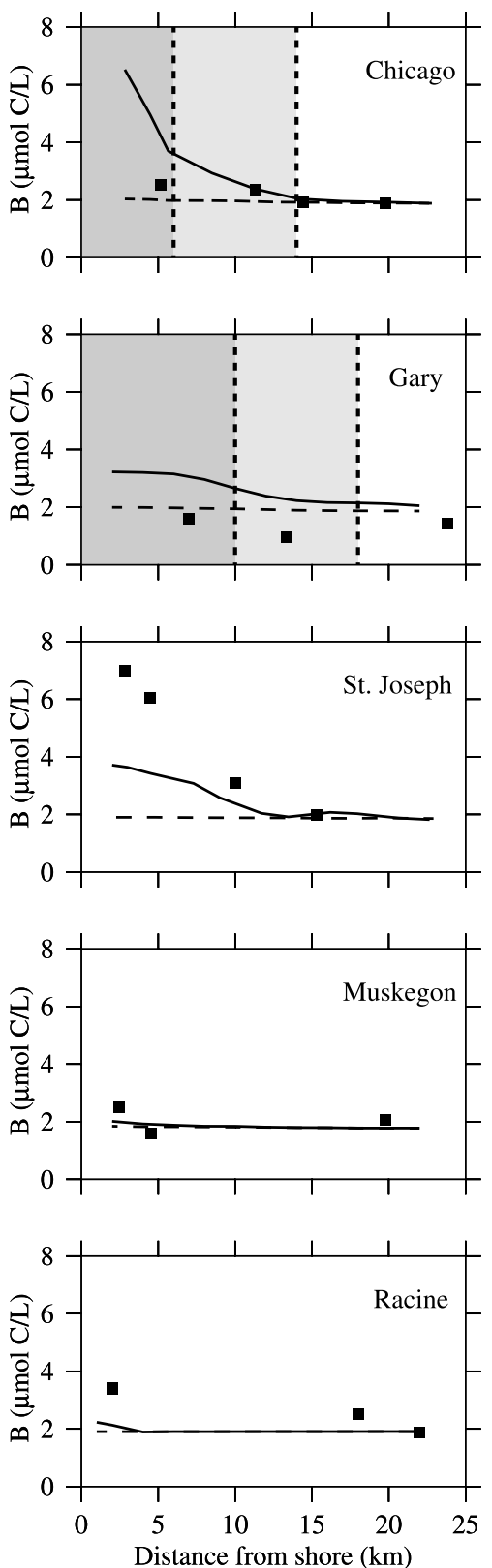

Case 3
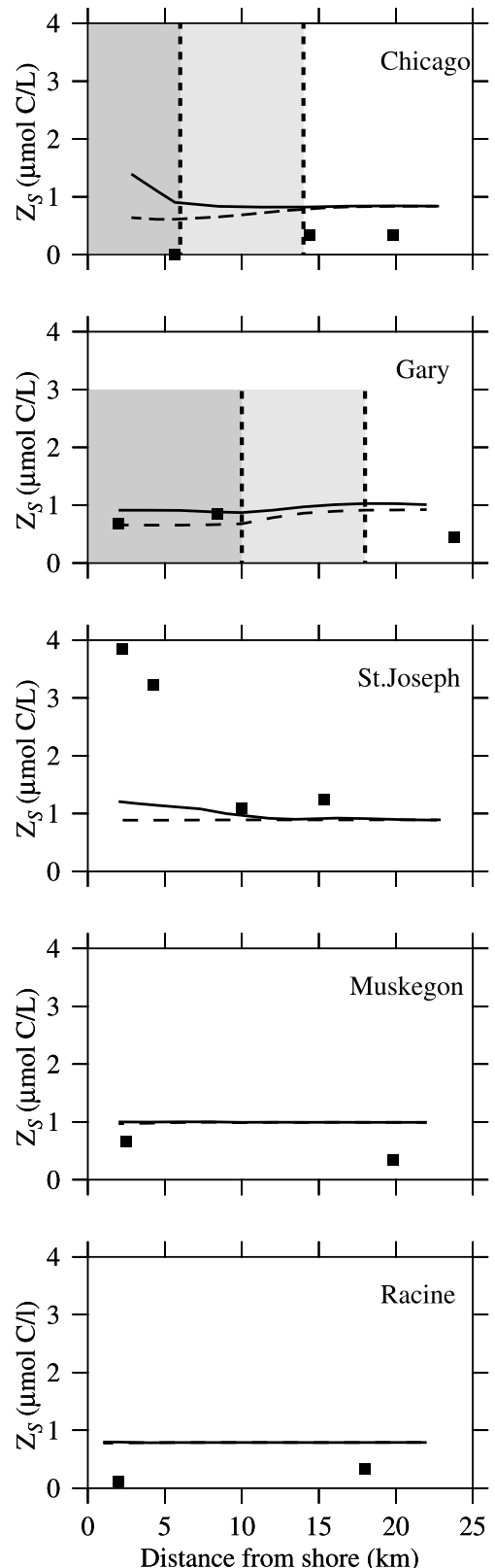

Figure 6. Comparisons of water samples with model-predicted bacteria and small zooplankton concentrations for numerical experiment cases 1 and 3 at Chicago, Gary, St. Joseph, Muskegon, and Racine transects for the March 1999 plume event. Solid squares indicate water samples. Areas with dark and light shading are the plume zone and transition zone from the plume to the interior.

1999. The model was spun up over the two months starting on 1 January and model-data comparisons were made over the plume period after 1 March. Temperature and biological variables were assumed to be uniformly distributed at the initial time. The initial value of temperature was $2^{\circ} \mathrm{C}$ everywhere. The observational data taken on 15 February 1999 were used to specify the initial values of the biological variables. They were $0.006 \mu \mathrm{mol} \mathrm{P} / \mathrm{L}$ for phosphorus, $1.2 \mu \mathrm{mol} \mathrm{C} / \mathrm{L}$ for large phytoplankton, $1.2 \mu \mathrm{mol} \mathrm{C} / \mathrm{L}$ for small phytoplankton, $0.3 \mu \mathrm{mol} \mathrm{C} / \mathrm{L}$ for large zooplankton, $0.4 \mu \mathrm{mol} \mathrm{C} / \mathrm{L}$ for small zooplankton, $2.0 \mu \mathrm{mol} \mathrm{C} / \mathrm{L}$ for bacteria, and $16 \mu \mathrm{mol} \mathrm{C} / \mathrm{L}$ for detritus, respectively.
[11] Unlike our previous modeling studies in Lake Michigan, no nutrient releases were considered in the modeling experiments. Instead, nutrients were supplied by remineralization of resuspended detritus, while the satellite-derived surface sediment concentration was only used to determine the light attenuation coefficients.

\section{Model Results}

[12] To determine quantitatively the effect of benthic detrital flux on heterotrophic production in southern Lake Michigan, numerical experiments were carried out for 4 
Mar. 6
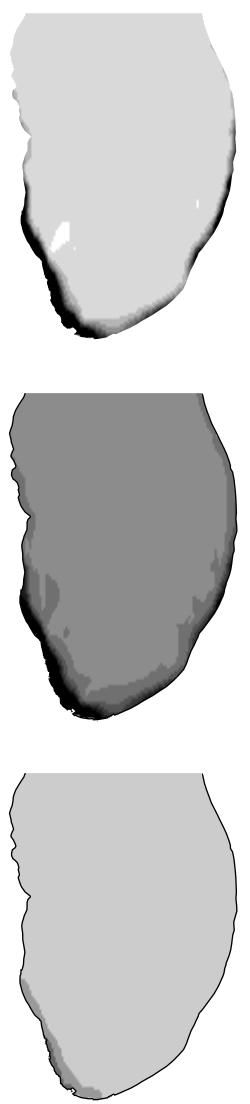

Mar.11
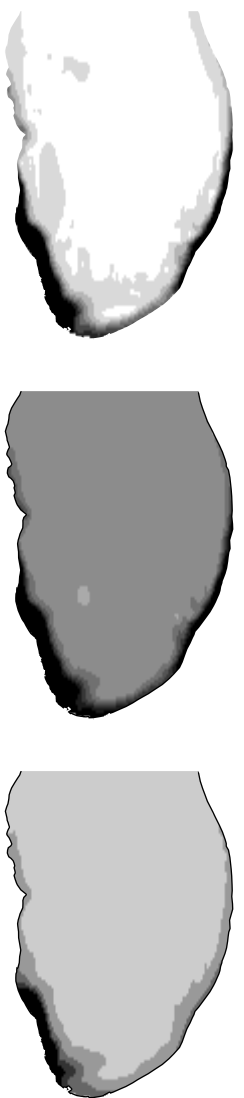

Mar.16
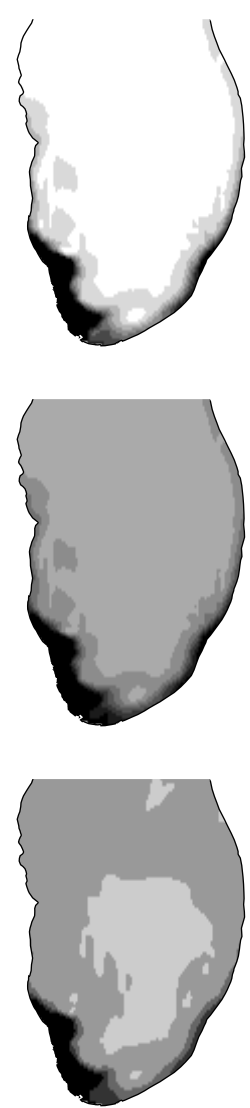

Mar.21
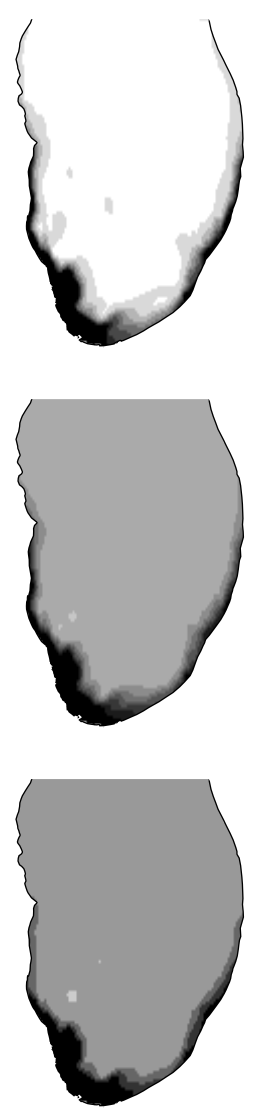

$\mathrm{D}(\mu \mathrm{mol} \mathrm{C} / \mathrm{L})$

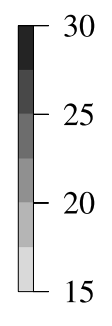

B $(\mu \mathrm{mol} \mathrm{C} / \mathrm{L})$

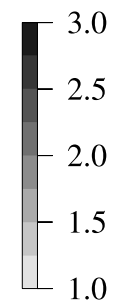

$\mathrm{Z}_{S}(\mu \mathrm{mol} \mathrm{C} / \mathrm{L})$

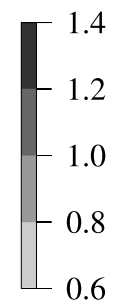

Figure 7. Snapshots of the distributions of model-computed detritus, bacteria, and small zooplankton concentrations on 6, 11, 16, and 21 March of 1999 in southern Lake Michigan.

different cases. In case 1: benthic fluxes and river discharges were ignored, and biological parameters were uniformly distributed. In case 2: benthic flux and river discharges were ignored, but the cross-shore distribution of bacteria growth was specified by using recent observational data taken by Cotner [2000]. In case 3: the benthic flux was considered, while river discharges were ignored. In case 4 , both benthic flux plus river discharges were included. Comparisons were made for results obtained from these 4 cases.

[13] On the basis of field measurements, Cotner [2000] reported that there was an offshore decrease in the growth rate of bacteria. It was $0.12 \mu \mathrm{mol} / \mathrm{L}$ per day near the shore, but decreased to $0.01 \mu \mathrm{mol} / \mathrm{L}$ per day in the interior. This cross-shore gradient was taken into account in case 2 , where the maximum growth rate of bacteria was specified as $0.12 \mu \mathrm{mol} / \mathrm{L}$ per day in the regions where bathymetry was $30 \mathrm{~m}$ or less and then linearly decreased to $0.01 \mu \mathrm{mol} / \mathrm{L}$ per day over a distance from $30-\mathrm{m}$ isobath to $60-\mathrm{m}$ isobath. However, model results obtained from cases 1 and 2 showed no significant difference in terms of the temporal and spatial distributions of detritus, bacteria, and microzooplankton. This suggests that because of the growthmortality cancellation the heterotrophic production during the plume event was not influenced by spatially nonuniform distribution of the growth rate of bacteria. Therefore no further discussion of case 2 results is included.
[14] In case 1, the model results clearly show that in the absence of detrital flux, the phosphorus, detritus and bacteria remained uniform in space (Figures 5 and 6(left)), though a noticeable decrease was found toward the onshore direction in microzooplankton within the plume area (Figure 6 (right)). This implies that if phosphorus, detritus and bacteria were uniformly distributed in space before the plume event, they would remain spatially uniform whether or not the plume occurred. These characteristics indirectly suggest that advection had no a significant influence on the spatial distribution of heterotrophic variables in southern Lake Michigan during the plume season. Small zooplankton grew up to about $0.8 \sim 1.0 \mu \mathrm{mol} \mathrm{C} / \mathrm{L}$ in March. On the Chicago and Gary transects, small zooplankton seemed less abundant inside the plume than outside the plume. Since bacteria remained spatially uniform during the simulation time and constant mortality and egestion rates were specified, the cross-shore structure of small zooplankton was directly related to small phytoplankton.

[15] In case 3, including the detritus flux at the bottom significantly improved the simulation results in terms of the observed cross-shore distribution of phosphorus and detritus concentrations (Figure 5). On the Chicago and Gary transects, for example, the model-computed phosphorus and detritus concentration increased dramatically shoreward, which showed a better match with observed values measured from water samples. On the St. Joseph, Muskegon, 
Water sample Model-result
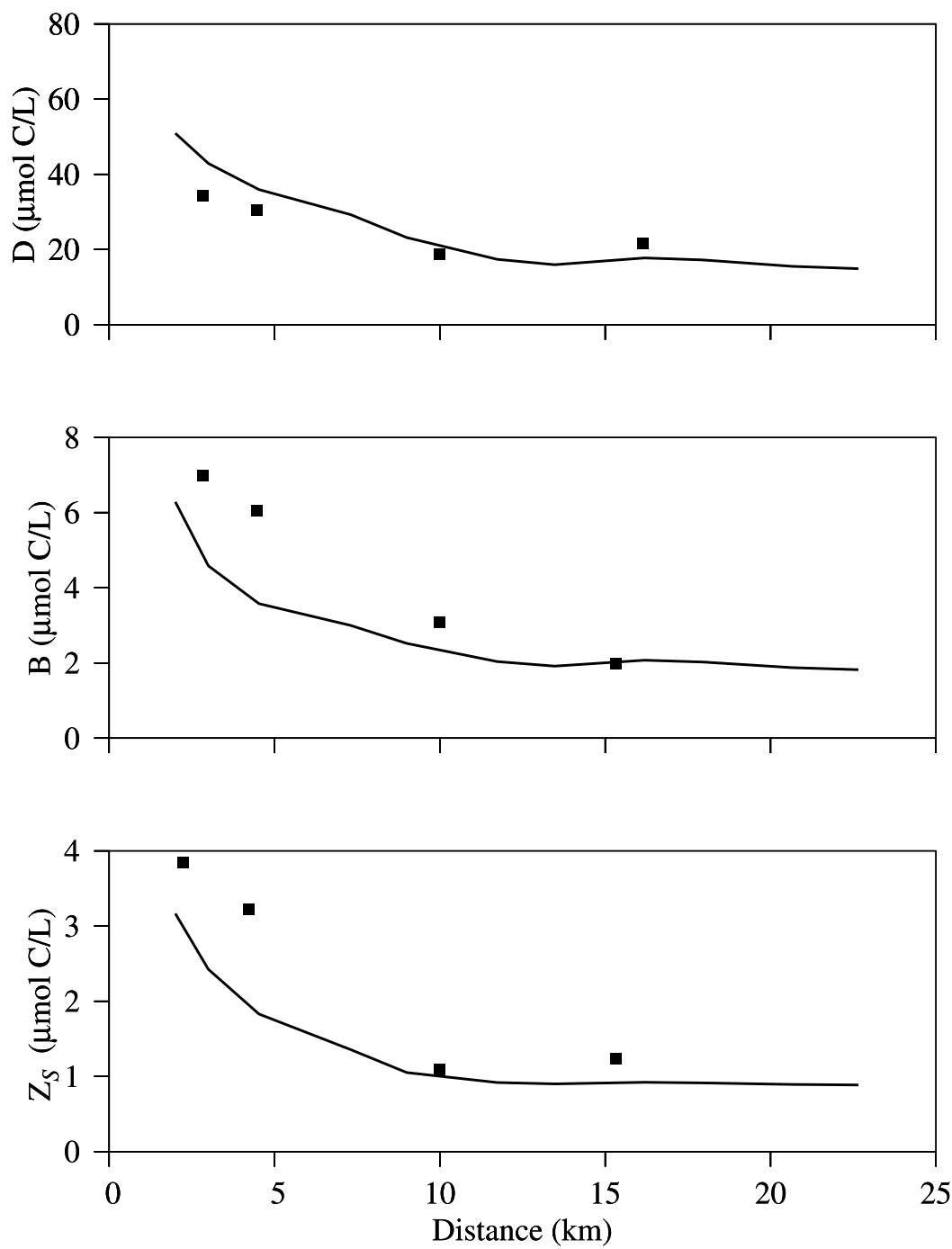

Figure 8. Comparisons of water samples with model-computed detritus, bacteria, and small zooplankton on the St. Joseph transect for the numerical experiment case 4 with both benthic flux and river discharges.

and Racine transects, the phosphorus concentration remained a low level and also showed little variation in the cross-shore direction. More evidence can be seen in snapshots of the nearsurface distribution of model-computed detritus on 6,11 , 16, and 21 of March, 1999 (Figure 7). A relatively high detrital concentration band found in the nearshore area along the southwestern coast was very similar to the distribution of SSC detected from remote sensing (Figure 3). Because the model-computed distributions of phosphorus and detritus concentrations were in good agreement with observations, it highly likely that the bottom detrital flux was sufficient to supply phosphorus by remineralization and detritus from wind-induced bottom suspension.

[16] Corresponding to the increase of detrital concentration in the plume, the model predicted a significant growth of bacteria inside the plume area. The model-predicted bacteria concentration increased shoreward in parallel with the cross-shore distribution of model-predicted detritus. This model result was consistent with the heterotrophic model dynamics in which the energy flux from detritus to bacteria was proportional to the detritus concentration. However, the model-predicted cross-shore distribution of bacteria was opposite to the actual bacteria measurements on the Chicago and Gary transects. These data showed a shoreward decrease of the bacteria concentration inside the plume, which completely differed from the model results. Recent field measurements and laboratory experiments reported two interesting findings regarding the growth of bacteria [Biddanda and Cotner, 2002]. First, the respiration rate of bacteria in the plume was unusually high (usually $>50 \%$ ), and Second there was a negative relationship between water temperature and bacterial growth efficiency. During the occurrence of the plume in March 1999, the model showed a significant temperature variability in the nearshore region where the plume occurred. This suggests 

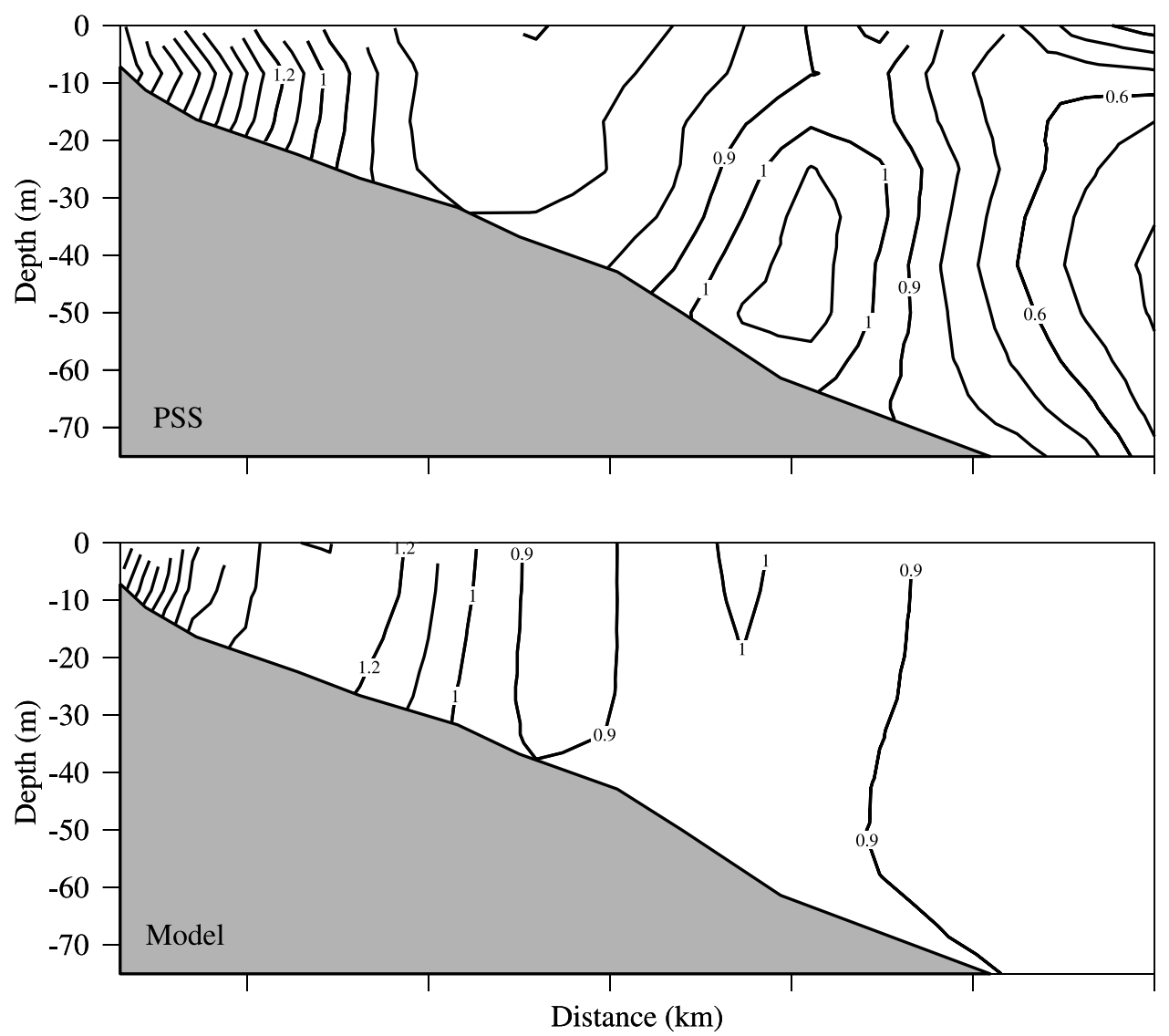

Figure 9. Comparison of the cross-shore distribution of zooplankton (top) derived from the tow-yoed Plankton Survey System (PSS) and (bottom) computed by model for the case with benthic flux and river discharges.

that the bacterial growth efficiency probably varied significantly with time in the plume, which probably directly contributed to the shoreward decrease of the bacteria concentration observed on the Chicago and Gary transects. This factor, however, was not taken into account in our current modeling effort. It is not surprising that a poor agreement was also found between model-predicted and observed microzooplankton on transects near Chicago and Gary, since the growth of microzooplankton in the model was controlled by grazing of bacteria.

[17] Additional important evidence was that for both cases 1 and 3 the model-predicted concentrations of detritus, bacteria and microzooplankton on the St. Joseph transect, a region outside the plume, were lower than the observed values measured in water samples The St. Joseph transect was located close to the edge of the SSC plume. The model showed that the bottom detrital flux, though it was much smaller compared with that inside the plume, significantly increased the detritus concentration in the plume. This increase, however, was not sufficient to reproduce the high concentration measured in water samples. What was still missed in our model experiments? The answer was "river discharges".

[18] In case 4, river discharge rates for 7 Rivers (see Figure 1) were specified using the climatologic average values listed by $J i$ et al. [2002]. The bacteria concentration at each river was specified as $4.8 \mu \mathrm{mol} \mathrm{C} / \mathrm{L}$. This value was chosen on the basis of field data collected during the EEGLE 10-14 March 1999 survey. Adding river discharges significantly improved the simulation result of bacteria and microzooplankton on the St. Joseph transect. The model-computed cross-shore distributions of bacteria and microzooplankton were in much better agreement with water samples (Figure 8). This suggests that the river flux was one of key processes controlling the nearshore distributions of bacteria and microzooplankton concentrations close to rivers. Bacteria abundance adjacent to the St. Joseph River was higher than other regions, which was due to the proximity of the river in relation to the wastewater treatment plant.

[19] River discharges also directly contributed to the cross-shore distribution of the total zooplankton biomass. The zooplankton biomass recorded by PSS shows a significant cross-shore gradient on the St. Joseph transect: about $2 \mu \mathrm{mol} \mathrm{C} / 1$ at the coast and decreasing to $0.6 \mu \mathrm{mol} \mathrm{C} / 1$ around the $30-\mathrm{m}$ isobath. This cross-shore feature was not resolved in case 3 , but was qualitatively captured in case 4 after river discharges were added (Figure 9). This further supports the importance of river inputs as a source of nutrients and organic matters to the nearshore ecosystem.

[20] The model experiments for case 1 and case 3 suggested that the temporal variation of $D$ in the plume was primarily controlled by the bottom detrital flux. This suggestion can be demonstrated by comparing the flux 


$$
\begin{array}{lll}
\mathrm{D}^{n+1}-\mathrm{D}^{n} & \cdots & \mathrm{D} \Leftrightarrow \mathrm{B} \text { flux } \\
\text { Benthic flux } & ---\mathrm{M} \rightarrow \mathrm{D} \text { flux }
\end{array}
$$

\section{Advection flux}
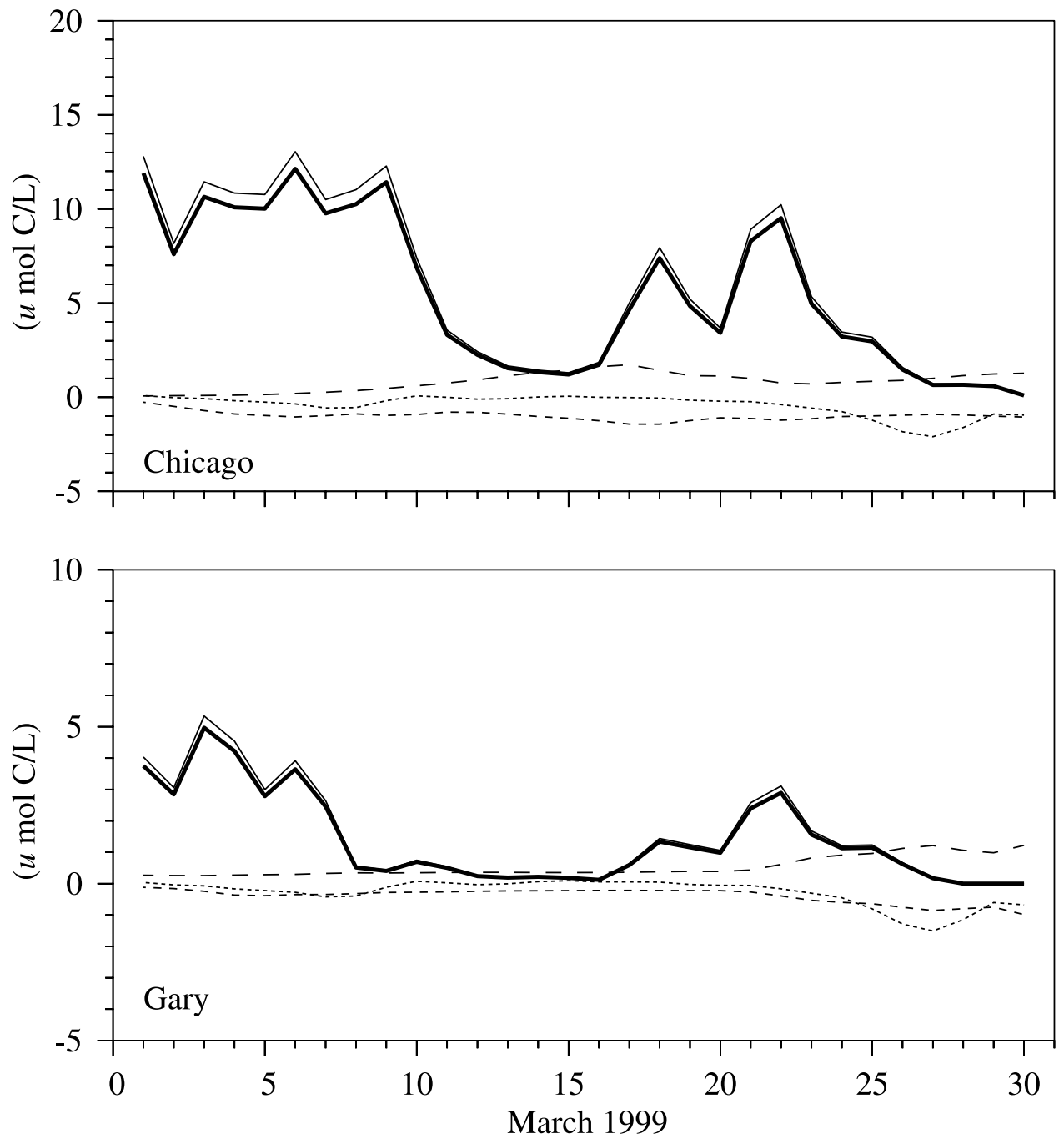

Figure 10. Time series of each term in the vertically averaged detritus equation at sites (top) B and (bottom) A.

estimation of each term in the detritus equation (Figure 10). In our current lower trophic level food web model, the detritus concentration in the water column was controlled by the sum of terms from (1) the bottom flux, (2) the bacteria-detritus $(B-D)$ interaction, (3) the mortality of phytoplankton and zooplankton, and (4) the advective transport produced by currents. The vertically averaged concentration of detritus at a fixed site was given as

$$
\begin{aligned}
\Delta D^{n}= & \bar{D}^{n+1}-\bar{D}^{n}=\frac{\Delta t}{H}\left[F_{e}+\int_{-H}^{0}(B \Leftrightarrow D) d z\right. \\
& \left.+\int_{-H}^{0}(M \rightarrow D) d z-\int_{-H}^{0} \nabla \cdot(\vec{V} D) d z\right],
\end{aligned}
$$

where $F_{e}$ presented the bottom detrital flux, $B \Leftrightarrow D$ : a net flux between $B$ and $D$,: the flux of plankton to $D$ due to mortality, $\nabla \cdot(\vec{V} D)$ : the convergence or divergence of $D$ due to advective currents, $n$ : an index of the $n$th step for time integration, and $\Delta t$ : the numerical time step. At the sites off Chicago and Gary (Figure 10), for example, $B \Leftrightarrow D, M \rightarrow D$ and advective fluxes were one order of magnitude smaller than $F_{e}$ during the period of strong sediment resuspension. This indicated that the detritus in the water column during the plume event was supplied mainly by the upward flux through sediment resuspension. Also, the spatial variation of the $D$ concentration was caused by the spatial variation of the intensity of sediment resuspension.

\section{Discussion}

[21] Our modeling experiments clearly showed that the bottom detrital flux was an important source for nutrients and detritus in the water column during the March 1999 plume. In our previous modeling efforts, the flux due to 


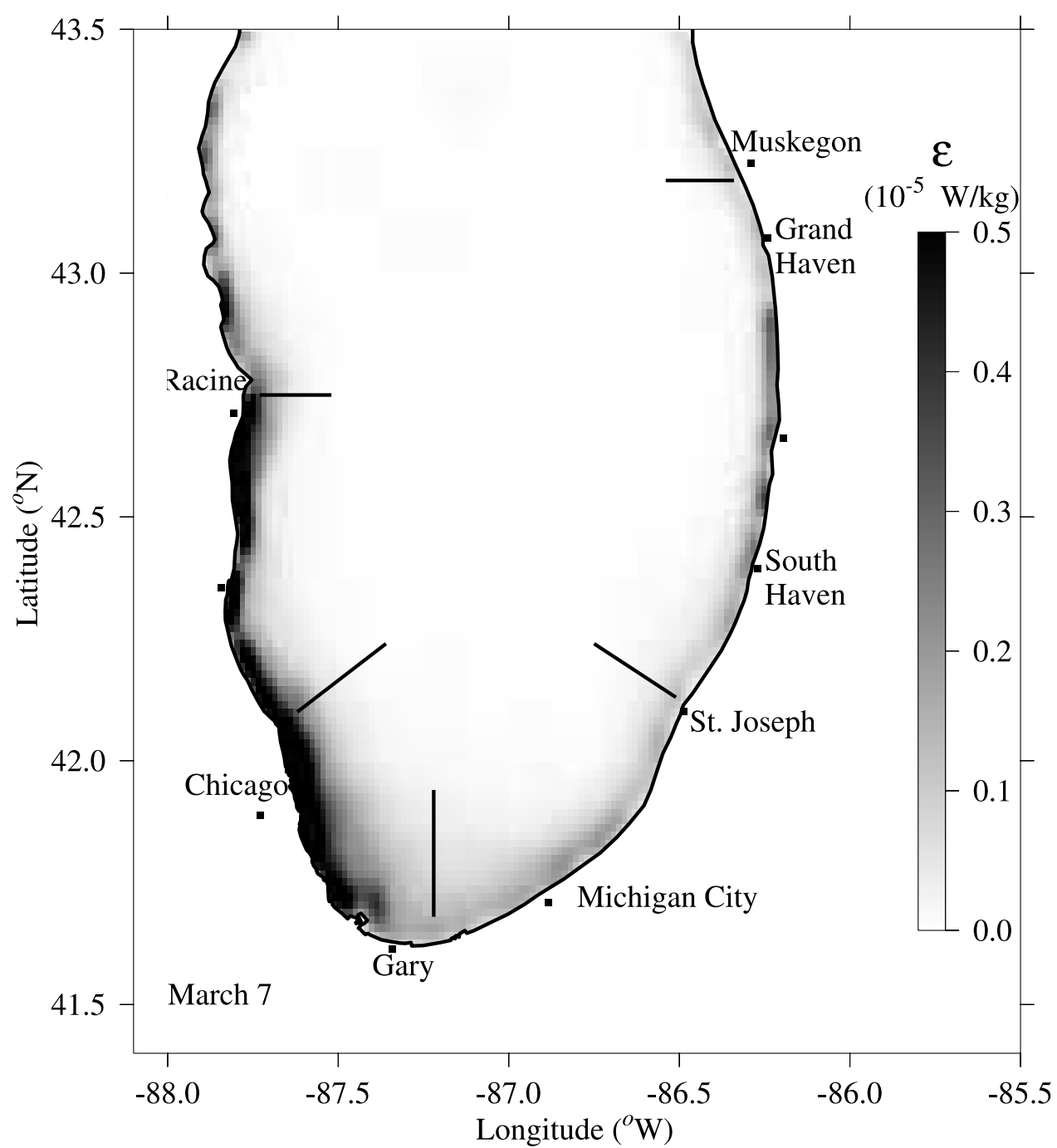

Figure 11. The distribution of turbulent dissipation $\left(\varepsilon: \mathrm{kg} / \mathrm{m}^{3}\right)$ in southern Lake Michigan on 7 March 1999.

sediment resuspension was indirectly taken into account through a nutrient release process from the suspended sediment [Ji et al., 2002; Chen et al., 2004]. Because the water was vertically well mixed in March in southern Lake Michigan, the satellite-derived surface SSC could represent the concentration of suspended sediment throughout the water column. Therefore the nutrients released from the suspended detritus could be determined easily by a statistical relationship between nutrients and SSC. This approach, however, failed to simulate the biological field when water became stratified and suspended sediment was restricted below the thermocline. In the modeling experiments described in this study, incorporating a synoptic-scale wave model into the biophysical model provided a physical process for the upward flux of detritus from the bottom. Success in simulating the spatial distribution of phosphorus and detritus during the March 1999 plume event allowed us to apply the biophysical model to study the seasonal variability of autotrophic and heterotrophic production in southern Lake Michigan.

[22] It should be pointed out here that our model failed to resolve the cross-shore distribution of bacteria and micro- zooplankton on the Chicago and Gary transects. This suggests that heterotrophic process during the plume event was related to more complex biophysical processes in addition to those included in our current lower trophic level food web model. For example, the negative correlation between bacteria respiration and water temperature detected from the recent field measurements implied that the growth rate of bacteria in the plume might vary significantly with space. This spatial variation must be taken into account in simulating the heterotrophic production. Another important finding was the impact of turbulent mixing on the growth of plankton during plume events (H. A. Vanderploeg, Anatomy of the recurrent coastal plume in Lake Michigan: The importance of turbulence, suspended sediments, and zebra mussels on nutrient and plankton distributions, submitted to Journal of Geophysical Research, 2004, hereinafter referred to as Vanderploeg, submitted manuscript, 2004). On the basis of the threshold criterion value of the turbulence dissipation rate $\left(\geq 10^{-5} \mathrm{~kg} / \mathrm{m}^{3}\right)$ at which plankton could be injured, Vanderploeg (submitted manuscript, 2004) suggested that the shoreward decrease of microzooplankton near the Chicago area during the 1999 plume event was 
probably related to wind-induced energetic turbulence mixing. A turbulence dissipation band of $>10^{-5} \mathrm{~kg} / \mathrm{m}^{3}$ was detected inside the plume area during March 1999, supporting Vanderpoeg's suggestion (Figure 11). A further modeling experiment should be conducted to verify quantitatively the impact of turbulence on plankton during the plume event in southern Lake Michigan.

\section{Conclusion}

[23] Roles of the bottom sediment resuspension in the heterotrophic level food web process in Lake Michigan were examined using a three-dimensional (3-D) coupled biological and physical model. The model was driven by the meteorological forcings (wind stress and heat flux) observed on the surface buoys in March 1999. The initial conditions of biological and physical variables were specified on the basis of the field measurement data taken in February 1999. A synoptic surface wave model was incorporated into the physical model to drive the benthic flux at the bottom.

[24] Four cases of experiments were conducted to examine the contributions of the upward detrital flux and river discharges to heterotrophic production during the plume events. By including the detrital flux at the bottom, the model provided a reasonable simulation of the cross-shore distributions of phosphorus and detritus concentrations observed around southern Lake Michigan. It highly likely that the bottom detrital flux was sufficient to supply phosphorus by remineralization and detritus from windinduced bottom suspension in the plume. River discharges seemed to be a key process that controlled the nearshore distributions of bacteria and microzooplankton concentrations in the region close to the rivers and outside the plume.

[25] The model result not only supported observed and previous modeling findings on the essential role of the microbial process in the ecosystem balance under the suspended sediment plume environment, but also provided insights into the physical mechanism for the maintenance of the microbial food web in southern Lake Michigan. Numerical approaches used in this study allow us to apply our coupled biological and physical model to study the seasonal variability of autotrophic and heterotrophic production in southern Lake Michigan. This modeling study suggests that the impacts of water temperature and turbulence dissipation must be taken into account in order to simulate the cross-shore distribution of bacteria and microzooplankton concentrations inside the plume.

[26] Acknowledgments. This research was supported by the NSF/ NOAA EGGLE Program under the NSF grant number OCE-9712869 and OCE0196543 for Changsheng Chen, OCE-9712872 for Judy W. Budd, NOAA Coastal Ocean Program grant for David J. Schwab, Dmitry Beletsky, James Cotner, Brian Eadie, Henry Vanderploeg and Peter J. Lavrentyev. Lixia Wang is supported by Chen's NSF grant.

\section{References}

Beletsky, D., D. J. Schwab, P. J. Roebber, M. J. McCormick, G. S. Miller, and J. H. Saylor (2003), Modeling wind-driven circulation during the
March 1998 sediment resuspension event in Lake Michigan, J. Geophys. Res, 108(C2), 3038, doi:10.1029/2001JC001159.

Biddanda, B. A., and J. B. Cotner (2002), Love handles in aquatic ecosystems: The role of dissolved organic carbon drawdown, resuspended sediments, and terrigenous inputs in the carbon balance of Lake Michigan, Ecosystems, 5, 431-445.

Blumberg, A. F., and G. L. Mellor (1987), A description of a threedimensional coastal ocean circulation model, in Three-Dimensional Coastal Ocean Model, Coastal Estuarine Sci., vol. 4, edited by N. S. Heaps, pp. 1-6, AGU, Washington, D. C.

Budd, J. W., D. S. Warrington, V. Ransibrahmanakul, and J. D. Chye (2000), Episodic events and trophic pulses: Estimating surface chlorophyll concentrations and transport using SeaWiFS imagery, Eos. Trans. $A G U, 80(49)$, Ocean Sci. Meet. Suppl., OS41C-13.

Chen, C., et al. (2002), A model study of the coupled biological and physical dynamics in Lake Michigan, Ecol. Modell., 152, 145-168.

Chen, C., L. Wang, R. Ji, J. W. Budd, D. J. Schwab, D. Beletsky, G. L. Fahnenstiel, H. Vanderploeg, B. Eadie, and J. Cotner (2004), Impacts of suspended sediment on the ecosystem in Lake Michigan: A comparison between the 1998 and 1999 plume events, J. Geophys. Res., 109, C10S05, doi:10.1029/2002JC001687, in press.

Cotner, J. B. (2000), Intense winter heterotrophic production stimulated by benthic resuspension, Limnol. Oceanogr., 45, 1672-1676.

Cotner, J. B., and B. A. Biddanda (2002), Small players, large roles: Microbial influence on biogeochemical processes in pelagic aquatic ecosystems, Ecosystems, 5, 121-195.

Cotner, J. B., T. B. Johengen, and B. A. Biddanda (1999), Rapid bacterial production in extremely cold waters stimulated by benthic-pelagic exchanges, paper presented at Aquatic Sciences Meeting, Am. Soc. of Limnol. Oceanogr., Santa Fe, N.M.

Eadie, B. J., R. L. Chambers, W. S. Gardner, and G. W. Bell (1984), Sediment trap studies in Lake Michigan: Resuspension and chemical fluxes in the southern basis, J. Great Lake Res., 10, 307-321.

Eadie, B. J., et al. (1996), Recurrent coastal plume in southern Lake Michigan, Eos Trans. $A G U, 77,337-338$.

$\mathrm{Ji}$, R., et al. (2002), Influences of suspended sediments on the ecosystem in Lake Michigan: A 3-D coupled bio-physical modeling experiment, Ecol. Model., 152, 169-190.

Liu, P. C., D. J. Schwab, and J. R. Bennett (1984), Comparison of a twodimensional wave prediction model with synoptic measurements in Lake Michigan, J. Phys. Oceanogr., 14, 1514-1518.

Lou, J., D. J. Schwab, D. Beletsky, and N. Hawley (2000), A model of sediment resuspension and transport dynamics in southern Lake Michigan, J. Geophys. Res., 105, 6591-6610.

Mortimer, C. H. (1988), Discoveries and testable hypotheses arising from Coastal Zone Color Scanner imagery of southern Lake Michigan, Limnol. Oceanogr., 33, 203-226.

Schwab, D. J., J. R. Bennett, and P. Liu (1984), Application of a simple numerical wave prediction model to Lake Erie, J. Geophys. Res., 89, $3586-3592$.

Schwab, D. J., D. Beletsky, and J. Lou (2000), The 1998 coastal turbidity plume in Lake Michigan, Estuarine Coastal Shelf Sci., 50, 49-58.

Warrington, D. S., J. W. Budd, R. P. Stumpf, and S. A. Green (2000), Satellite-derived chlorophyll and turbidity estimates using SeaWiFS (Sea-Viewing Wide Field-of-view Sensor) imagery, paper presented at 43rd Annual Conference, Int. Assoc. for Great Lakes Res., Cornwall, Ont., Canada.

D. Beletsky, Department of Naval Architecture and Marine Engineering, University of Michigan, Ann Arbor, MI 48109, USA.

J. W. Budd, Department of Geological Engineering and Sciences, Michigan Technological University, Houghton, MI 49931, USA.

C. Chen, H. Liu, J. Qi, and L. Wang, School for Marine Science and Technology, University of Massachusetts-Dartmouth, New Bedford, MA 02744-1221, USA. (clchen@umassd.edu)

J. Cotner, Department of Ecology Evolution and Behavior, University of Minnesota, St. Paul, MN 55108, USA.

B. Eadie, T. Johengen, D. J. Schwab, and H. Vanderploeg, NOAA/ GLERL, 2205 Commonwealth Blvd., Ann Arbor, MI 48105-2945, USA.

P. J. Lavrentyev, Department of Biology, University of Akron, Akron, $\mathrm{OH} 44325$, USA. 